-S. Wasterlain, D. Candusso, D. Hissel, F. Harel, P. Bergman, P. Menard, M. Anwar (février 2010). Study of temperature, air dew point temperature and reactant flow effects on PEMFC performances using electrochemical spectroscopy and voltammetry techniques. J. Power Sources. Vol. 195, n²4, pp. 984-993. Ed. Elsevier.

\title{
Study of temperature, air dew point temperature and reactant flow effects on PEMFC performances using electrochemical spectroscopy and voltammetry techniques
}

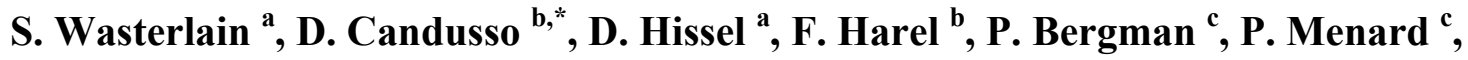 \\ M. Anwar ${ }^{c}$ \\ ${ }^{a}$ FEMTO-ST (UMR CNRS 6174), ENISYS department, University of Franche-Comté, \\ ${ }^{\mathrm{b}}$ INRETS, The French National Institute for Transport and Safety Research, \\ FCLAB, Techn'Hom, rue Thierry Mieg, 90010 BELFORT Cedex, FRANCE \\ ${ }^{\mathrm{c}}$ University of Connecticut, Connecticut Global Fuel Cell Center \\ Department of Electrical \& Computer Engineering, 44 Weaver Road, \\ Unit 5233, STORRS, CT 06269-5233, USA
}

* Corresponding author.

Tel.: +33 384583633 ;

Fax: +33384583636

E-mail addresses:

sebastien.wasterlain@utbm.fr (Sébastien Wasterlain), denis.candusso@inrets.fr (Denis Candusso),

daniel.hissel@univ-fcomte.fr (Daniel Hissel),

fabien.harel@inrets.fr (Fabien Harel),

tricia@engr.uconn.edu (Patricia Bergman),

menard@engr.uconn.edu (Peter Menard),

anwara@engr.uconn.edu (Medhi Anwar).

\begin{abstract}
A single PEMFC has been operated by varying the assembly temperature, the air dew point temperature and the anode/cathode stoichiometry rates with the aim to identify the parameters and combinations of factors affecting the cell performance. Some of the experiments were conducted with low humidified reactants (relative humidity of $12 \%$ ). The FC characterizations tests have been conducted using in-situ electrochemical methods based on load current and cell voltage signal analysis, namely: polarization curves, EIS measurements, cyclic and linear sweep voltammetries (CV and LSV). The impacts of the parameters on the global FC performances were observed using the polarization curves whereas EIS, CV and LSV test results were used to discriminate the different voltage loss sources. The test results suggest that some parameter sets allow maximal output voltages but can also induce material degradation. For instance, higher FC temperature and air flow values can induce significant electrical efficiency benefits, notably by increasing the reversible potential and the reaction kinetics. However, raising the cell temperature can also gradually dry the FC and increase the risk of membrane
\end{abstract}


failure. LSV has also shown that elevated FC temperature and relative humidity can also accelerate the electrolyte degradation (i.e. slightly higher fuel crossover rate) and reduce the lifetime consequently.

Keywords: PEMFC; Characterization; Electrochemical Impedance Spectroscopy; Cyclic Voltammetry; Linear Sweep Voltammetry

\section{Introduction}

Finding clean power sources is one of the main challenges of this century. One possible solution is the development of Fuel Cell (FC) generators with minimal carbon footprint. Currently, the Proton Exchange Membrane Fuel Cell (PEMFC) seems to be the most promising FC technology for transport applications. However, in order to be commercially and economically viable, the PEMFCs need to be cost-effective as well as durable [1]. Minimal lifetimes of $5000 \mathrm{~h}$ are required for $\mathrm{FC}$ stacks dedicated to vehicular applications. To reach this target, the durability of FC key components such as membrane/electrode assemblies and fuel processing catalysts must be improved. Lifetimes of over $1000 \mathrm{~h}$ at constant electrical load and $700 \mathrm{~h}$ under dynamical current switching have been reported in previous works [2,3]. To achieve long-term operation with stable FC performances, the monitoring and the characterization of critical cell parameters are crucial [4]. The physical stack parameters (e.g. electrolyte resistance, mass transport and charge transfer resistances, permeability of the membrane to electrons and fuel, true electrochemical activity of electrodes) are usually non-linear and depend not only upon the geometrical structure of the cell but also on the FC operating conditions and durations. A wide range of experimental techniques is available for the characterization of FC performances [5-8]. However, the number of in-situ methods (i.e. methods that allow the diagnosis of the $\mathrm{FC}$ assembly without disassembling it) mainly based on the observation of the FC electrical signals (i.e. load current, cell voltages) is quite restricted. The most common "electrical" method used to characterize FCs is certainly the polarization curve test. The cell Open Current Voltage (OCV) monitoring can also be useful for diagnosis purpose, in particular to detect failed cells in FC stacks [9]. In addition, the acquisition and analysis of physical FC parameters can be made using other well suited diagnostic tools like Electrochemical Impedance Spectroscopy (EIS). This technique can provide relevant information about the FC state of health and allow more efficient FC system controls. As an example that illustrates the importance of the stack parameter survey, the membrane resistance can be measured to estimate the electrolyte water content and achieve appropriate reactant humidification $[10,11]$. Electrochemical techniques like EIS can be used in combination with structural and chemical analyses like voltammetry experiments to correlate the performance of the investigated cell with the material properties of its various components. Recently, H.-T. Kim et al. have conducted an electrochemical analysis of a PEMFC operated at varying cathode Relative Humidity $(\mathrm{RH})$ and current density [12]. Some polarization curves, EIS diagrams and voltammetry graphs were used to understand how the FC performance is affected by the different factors and by a dry air feed.

In this paper, an experimental study of a PEMFC equipped with a perfluorinated ionomer membrane is reported. The effects of operating temperature, anode / cathode stoichiometry flow rates and air dew point temperature are investigated. In order to 
better understand the physical phenomena occurring in the cell, EIS, in-situ Cyclic Voltammetry (CV), Linear Sweep Voltammetry (LSV) and polarization curve (U-I curve) measurements are performed for selected parameter levels. The objective of the work is (i) to obtain a deeper understanding of the FC behavior using different in-situ electrochemical methods (in particular when the cell is fed by low humidified reactants), (ii) to develop and evaluate some "electrical" characterization methodologies which could be adapted and used in the frame of future FC vehicle applications.

In Section 2, the experimental set-up will be briefly described. The experimental results will be presented and discussed in Section 3.

\section{Experimental set-up and test procedures}

\subsection{Set-up}

The single PEMFC used in this study has been assembled with a commercial Membrane Electrode Assembly (MEA): Gore Primea series 5761, active cell area of $100 \mathrm{~cm}^{2}$ and membrane thickness of $18 \mu \mathrm{m}$ [13]. SGL $10 \mathrm{BB}$ graphite paper Gas Diffusion Layer (GDL) was used in this study with a porosity of $84 \%$ and a thickness of $16.5 \mu \mathrm{m}$ [14]. Graphite bipolar plates, aluminum end plates and steel current collector plates were manufactured by UBzM. The FC assembly operates at atmospheric pressure with pure hydrogen supplied at anode (with a constant dew point temperature of $20^{\circ} \mathrm{C}$ ) and humidified air at cathode. The nominal current is equal to $50 \mathrm{~A}$. The nominal $\mathrm{FC}$ temperature is ranging from 55 to $60^{\circ} \mathrm{C}$. The $\mathrm{FC}$ parameters, namely operating temperature, anode and cathode Relative Humidity rates (respectively RHa and RHc), are controlled using a home-made test bench. A description of this set-up can be found in [15]. The electrochemical workstation used in this study to investigate the FC behavior is a Zahner IM6 [16].

\subsection{Test conditions and methods}

\section{- Polarization Curves:}

The impacts on the FC performances of two $\mathrm{FC}$ temperatures $\left(\mathrm{T}=40\right.$ and $\left.60^{\circ} \mathrm{C}\right)$, two air dew point temperatures (Air dwpT $=20^{\circ} \mathrm{C}$ and $40^{\circ} \mathrm{C}$ ), two anode stoichiometry rates $(\mathrm{FSA}=2$ and 3$)$ and two cathode stoichiometry rates (FSC $=3$ and 5) were studied using U-I curves. The polarization curves were measured in decreasing current mode with a decrement of $0.2 \mathrm{~A}$ every $5 \mathrm{~s}$ for a starting current of $50 \mathrm{~A}$. During each polarization curve record, the stoichiometry rates were maintained constant at the specified levels. However, some minimal gas flow values computed for a $20 \mathrm{~A}$ load current were applied to ensure a better draining of the water out of the FC assembly and thus to obtain more stable operations (without large voltage fluctuation) at low power outputs.

\section{- Electrochemical Impedance Spectroscopy:}

EIS allows the supervision of physical parameters like membrane resistance and highlights the relative importance of mass and charge transfers. Impedance tests were carried out with two polarization currents $(35 \mathrm{~A}$ and $50 \mathrm{~A}$ ) and using an alternative current excitation of $2 \mathrm{~A}$ peak to peak. The frequency was ranged from $0.037 \mathrm{~Hz}$ to 30 
$\mathrm{kHz}$. The same parameter levels were selected for polarization curves and for EIS tests. The stability of the system was checked by monitoring the FC voltage output, but also the temperatures at water cell outlet, in the gas line supplies and in the humidifiers at both FC sides at the onset of generating each polarization curves. The system was considered stable when the cell voltage and the temperatures did not change during 20 min at nominal current. It took about 16 min to generate a trace.

\section{- Cyclic Voltammetry:}

The CV is a powerful tool that is widely employed by FC researchers to study the effects of contaminants on cell performances [17], to study the ability of the electrodes to adsorb/desorb hydrogen molecules [18] and also to analyze the effects of cold start [19]. In our experiments, the FC was supplied with hydrogen and nitrogen at anode and cathode, respectively. The impacts of flow rates were investigated. Three values were considered: $0.5 \mathrm{Nl} \cdot \mathrm{min}^{-1}, 1 \mathrm{Nl} \cdot \mathrm{min}^{-1}, 2 \mathrm{Nl} \cdot \mathrm{min}^{-1}$ at both sides. A sweep rate of $40 \mathrm{mV} \cdot \mathrm{s}^{-1}$ and a voltage range of $0.055 \mathrm{~V}-0.85 \mathrm{~V}$ were selected.

\section{- Linear Sweep Voltammetry:}

Another well-suited tool to study the FC behavior is the LSV. It is a powerful tool allowing the detection of hydrogen crossover and any internal short circuit between anode and cathode. In our tests, anode was fed with hydrogen while cathode was supplied with nitrogen. The impacts of flow rates, FC temperatures and air dew point were investigated. Three flow rates were selected: $0.5 \mathrm{Nl} \cdot \mathrm{min}^{-1}, 1 \mathrm{Nl} \cdot \mathrm{min}^{-1}$, and 2 $\mathrm{N} 1 \cdot \mathrm{min}^{-1}$ at both sides. The other test settings were similar to those employed for the polarization curves. The voltage range was $0.055 \mathrm{~V}-0.85 \mathrm{~V}$ with a sweep rate of 2 $\mathrm{mV} \cdot \mathrm{s}^{-1}$.

\section{Experimental results}

The matrix of the tests performed was done in accordance with a fractional experimental design [20]. Eight tests of the full design (16 experiments for four factors at two levels each) were selected and three additional tests were added. The eleven experiment conditions are reported in Table 1. The pairs of polarization curve tests and EIS experiments considered to study the various factor impacts are also listed in Table 1. For each one of the studies, the combination of tests is selected using a "one-factorat-a time" method which consists in holding all factors constant except the investigated one. The groups of CV and LSV experiments considered to study the various factor influences is displayed in Table 2. 
Table 1 - List of the tests performed (in chronological order). Electrolyte resistance and polarization resistance values measured during the EIS measurements. The different combinations of polarization curve tests (U-I tests) and EIS experiments considered (X) to study the different factor impacts.

\begin{tabular}{|c|c|c|c|c|c|c|c|c|c|c|c|}
\hline Test Nr. & $\begin{array}{c}0 \\
\text { (Nominal) } \\
\end{array}$ & 1 & 2 & 3 & 4 & 5 & 6 & 7 & 8 & 9 & 10 \\
\hline \multicolumn{12}{|l|}{ Factors: } \\
\hline $\mathrm{T}\left({ }^{\circ} \mathrm{C}\right)$ & 50 & 40 & 40 & 40 & 40 & 40 & 60 & 60 & 60 & 60 & 60 \\
\hline Air dwpT $\left({ }^{\circ} \mathrm{C}\right)$ & 40 & 40 & 40 & 40 & 20 & 20 & 20 & 40 & 20 & 40 & 40 \\
\hline FSA & 2 & 3 & 2 & 2 & 3 & 2 & 3 & 2 & 2 & 2 & 3 \\
\hline FSC & 4 & 3 & 5 & 3 & 5 & 3 & 3 & 3 & 5 & 5 & 5 \\
\hline \multicolumn{12}{|l|}{ EIS parameters : } \\
\hline $\begin{array}{l}\text { Electrolyte resistance } \\
(\mathrm{m} \Omega) \text { at } 35 \mathrm{~A}\end{array}$ & & 1.86 & 1.87 & 1.88 & 1.89 & 1.88 & 1.89 & 1.88 & 2.17 & 1.96 & 2.28 \\
\hline $\begin{array}{l}\text { Electrolyte resistance } \\
(\mathrm{m} \Omega) \text { at } 50 \mathrm{~A}\end{array}$ & & 1.86 & 1.88 & 1.79 & 1.89 & 2.03 & 2.07 & 1.87 & 2.24 & 1.92 & 2.29 \\
\hline $\begin{array}{l}\text { Polarization resistance } \\
(\mathrm{m} \Omega) \text { at } 35 \mathrm{~A}\end{array}$ & & 6.48 & 4.73 & 6.48 & 4.59 & 6.2 & 5.16 & 6.12 & 4.86 & 4.63 & 4.75 \\
\hline $\begin{array}{l}\text { Polarization resistance } \\
(\mathrm{m} \Omega) \text { at } 50 \mathrm{~A}\end{array}$ & & 7.01 & 4.70 & 6.80 & 4.63 & 7.26 & 5.16 & 6.45 & 4.53 & 4.25 & 4.51 \\
\hline \multicolumn{12}{|l|}{$\begin{array}{l}\text { U-I and EIS tests } \\
\text { considered to study: }\end{array}$} \\
\hline \multirow{2}{*}{ T impact } & & & $\mathrm{X}$ & & & & & & & $\mathrm{X}$ & \\
\hline & & & & $\mathrm{X}$ & & & & $\mathrm{X}$ & & & \\
\hline \multirow{2}{*}{ Air dwpT impact } & & & & $\mathrm{X}$ & & $\mathrm{X}$ & & & & & \\
\hline & & & & & & & & & $X$ & $\mathrm{X}$ & \\
\hline \multirow{2}{*}{ FSA impact } & & $\mathrm{X}$ & & $\mathrm{X}$ & & & & & & & \\
\hline & & & & & & & & & & $\mathrm{X}$ & $\mathrm{X}$ \\
\hline \multirow{2}{*}{ FSC impact } & & & $X$ & $\mathrm{X}$ & & & & & & & \\
\hline & & & & & & & & $\mathrm{X}$ & & $\mathrm{X}$ & \\
\hline
\end{tabular}

The effects of the parameters (fuel cell temperature, air dew point temperature, stoichiometry rates) are studied using the various characterization methods, namely polarization curves, EIS, LSV and CV. The duration of the complete characterization sequence can be estimated to about $50 \mathrm{~h}$.

\subsection{Effects of operating temperature on the $\mathrm{FC}$ performances}

The operating temperature can affect the PEMFC voltage in different ways. If the reversible Open Circuit Voltage is theoretically lower for higher cell temperatures [21], raising the cell temperatures enhances reaction kinetics and contributes to obtain lower activation losses $[22,23]$. In practice, PEMFC voltages are usually enhanced at higher temperatures but the benefit of increasing the temperature is limited by the ability of the perfluorosulfonic membranes to keep sufficient water content and to provide adequate conductivities. Usually, stack temperature references do not exceed $90^{\circ} \mathrm{C}$ (glass 
transition temperature of Nafion membranes) to prevent overheating damage [24]. From the FC system point of view, increasing the cell temperature has also some benefits, especially for vehicle applications. The waste heat obtained from higher-temperature cells is more useful: more compact external heat exchangers can be used and a better tolerance to pollutants can possibly be achieved. The problem of the temperature impacts is addressed below using the four electrochemical characterization techniques described in Section 2.2.

\section{- Polarization curve results:}

Polarization curves provide important information on the behavior of FCs (for instance by the identification of parameters such as the Tafel slope [21]). However, they do not facilitate the understanding of the underlying physical mechanisms that occur within the assembly. Polarization curves are mainly a measure of the global PEMFC performance. The pair of Tests 3 and $7\left(\mathrm{~T}=40\right.$ and $60^{\circ} \mathrm{C}$ respectively) can be considered to estimate the influence of the FC operating temperature through the U-I curve (and EIS) results because these experiments have been performed in the same conditions of stoichiometries $(\mathrm{FSA}=2$ and $\mathrm{FSC}=3)$ and air dew point temperature $\left(40^{\circ} \mathrm{C}\right)($ Table 1$)$. For comparisons, the combination of Tests 2 and 9 (with FSA $=2 ; \mathrm{FSC}=5$ and Air dwpT $=40^{\circ} \mathrm{C}$ ) can also be used to estimate the impact of the temperature on the $\mathrm{FC}$ performances measured using the U-I (and EIS) curves.

At low cathode stoichiometry rates (FSC $=3$ in Tests 3 and 7), the benefit of higher FC temperature on the cell voltage is observed (Fig. 1a). At $10 \mathrm{~A}$, the output voltage of the curve related to Test 7 increases by $+10 \mathrm{mV}$ with regard to Test 3. A larger gap is revealed for higher currents. At $50 \mathrm{~A}$, the potential difference increases up to $+20 \mathrm{mV}$. In [25], a potential difference of $170 \mathrm{mV}$ was observed at a current density of $0.5 \mathrm{~A} / \mathrm{cm}^{2}$ and for an increase of the $\mathrm{FC}$ temperature from $50^{\circ} \mathrm{C}$ to $70^{\circ} \mathrm{C}$. At the opposite of [25], where the $\mathrm{FC}$ was fed with fully humidified gases, our measurements were done considering low humidified reactants, especially at anode $(\mathrm{RHa}=31.7 \%$ and $\mathrm{RHc}=$ $100 \%$ for a $\mathrm{FC}$ temperature of $40^{\circ} \mathrm{C}$; $\mathrm{RHa}=11.7 \%$ and $\mathrm{RHc}=37 \%$ for a $\mathrm{FC}$ temperature of $60^{\circ} \mathrm{C}$ ). In our experiments, the benefit of higher $\mathrm{FC}$ temperature is hindered by other possible losses (reduction of the true ECA, increase of ohmic losses, increase of the gas crossover effect) induced by a too low humidity in the FC assembly. For higher flow rates ( $\mathrm{FSC}=5$ in Tests 2 and 9 , with $\mathrm{T}=40$ and $60^{\circ} \mathrm{C}$ respectively), the benefits of elevated FC temperature are not so obvious. At low current densities, where the water production by the oxygen reduction is not sufficient to hydrate correctly the membranes and the Pt active sites, a higher flow rate combined with a higher temperature induces a drying of the membrane. The phenomena observed for a FC temperature of $40^{\circ} \mathrm{C}$ are more pronounced at $60^{\circ} \mathrm{C}$. At this temperature level, the overpotentials reflecting the different losses in the cell are higher. As a result, the usual advantage of operating FCs at elevated temperature (e.g. enhanced reaction kinetics) is hidden. However, when the FC current density increase, the MEA drying phenomena can be partially recovered and thus, the benefit of higher FC temperature might be more significant (polarization curves of Tests 2 and 9).

\section{- Impedancemetry results:}

All the impedance spectra are displayed using Nyquist plots for an easier interpretation of the results. Figure $1 \mathrm{~b}$ shows the effects of the temperature for a polarization current of $35 \mathrm{~A}$, whereas the impedance results obtained for a 50 A load are displayed in Fig. 
1c. Table 1 summarizes also two key points of the impedance spectra, namely the electrolyte resistances and the polarization resistances. The temperature effect on the membrane resistance has been largely discussed in the literature. Increasing the FC temperature can participate to the reduction of the amount of water in the electrolyte and thus cause a drop-down of the membrane conductivity, in particular when the reactants are not sufficiently hydrated. A higher temperature can also lead to a higher diffusivity of the hydrogen protons in the electrolyte membrane, thereby reducing the electrolyte resistance and the potential ohmic losses in the membrane. However, this phenomenon happens if the membrane water uptake is sufficient [25].

At low cathode stoichiometry rates ( $\mathrm{FSC}=3$ in Tests 3 and 7), the membranes have the same conductivities $(1.88 \mathrm{~m} \Omega)$. The lower cathodic $\mathrm{RH}$ induced by the increase of the FC temperature does not impact the membrane resistance at low FSC (FSC $=3$ ). No major impact of the polarization current value on the membrane resistance value is revealed. In both cases ( $35 \mathrm{~A}$ and $50 \mathrm{~A}$ ), the impedance spectra are dominated by the phenomena of species diffusion, which lead to worse cell performances. At $35 \mathrm{~A}$, the benefit of a higher FC temperature cannot be observed in the high frequency loop (from $5 \mathrm{kHz}$ to $5 \mathrm{~Hz}$ ) related with charge transfers (protons and electrons). This invariance suggests that the water contents in the membrane and in the electrodes are sufficient to promote the reactions. However, in the low frequency region (from $5 \mathrm{~Hz}$ to $37 \mathrm{mHz}$ ), the diffusion of species is affected by the temperature of the assembly. A higher temperature leads to a reduced diffusion loop and mainly to a better diffusion of oxygen at cathode (which is likely due to a better removal of water droplets out of the oxidant compartment). Between Tests 3 and 7, the mass transfer resistance estimated at $35 \mathrm{~A}$ is diminished of about $-5.6 \%$. At $50 \mathrm{~A}$, the same conclusions can be done except for the charge transfer loop: a slight enhancement is observed when the temperature raises from 40 to $60^{\circ} \mathrm{C}$. The mass transfer resistance is also expected to diminish of $-7.8 \%$.

The observations are not identical for higher flow rates (FSC $=5$ in Tests 2 and 9). An increase of the electrolyte resistance from 1.87 to $1.96 \mathrm{~m} \Omega(+4.8 \%)$ can be detected with the rise of the temperature from $40^{\circ} \mathrm{C}$ (Test 2) to $60^{\circ} \mathrm{C}$ (Test 9). This is due to a higher water removal out of the FC which is induced by the higher oxidant flow rates. For both current values ( $35 \mathrm{~A}$ and $50 \mathrm{~A}$ ), the impedance spectra are dominated by charge diffusion processes. At $35 \mathrm{~A}$, no change is observed in the high frequency loop, whereas a little evolution can be detected in the species diffusion loop. A higher temperature reduces the polarization resistance of $-2.1 \%$. At $50 \mathrm{~A}$, the impedance results obtained with the highest temperature (Test 9) show clearly a better FC behavior in terms of charge transport and mass diffusion processes (mass transfer resistance is reduced of $-9.6 \%)$, even if the gas humidities are quite low at $60^{\circ} \mathrm{C}(\mathrm{RHa}=37 \%, \mathrm{RHc}=$ $11.7 \%$ ). However, at $50 \mathrm{~A}$, the membrane resistance is slightly increased by the higher cell temperature $(+2.1 \%$ between Tests 2 and 9$)$.

\section{- CV voltammogram results:}

As shown in Table 2 and Fig. 1d, the $\mathrm{CV}$ tests were performed at two operating temperatures $\left(\mathrm{T}=40^{\circ} \mathrm{C}\right.$ and $60^{\circ} \mathrm{C}$ ) with air dew points temperature (Air dwpT) equal to $20^{\circ} \mathrm{C}$ and $40^{\circ} \mathrm{C}$. Four groups of tests (Tests 1, 2, 3; Tests 4, 5; Tests 6, 8; Tests 7, 9, 10) can be identified in Table 2 . In each group of tests, the experiments are performed in the same conditions of cell and air dew point temperatures, but for three different gas flow rates. In order to study the FC temperature impact on the $\mathrm{CV}$ results (i.e. ECA value and shapes of the diagrams), Tests 4,5 can be compared to Tests 6,8 since all these 
experiments were conducted with the same air dew point temperature $\left(20^{\circ} \mathrm{C}\right)$. Besides, Tests $1,2,3$ can also be compared to Tests 7, 9, 10 (Air dwpT $\left.=40^{\circ} \mathrm{C}\right)$.

In the test conditions considered, a higher FC temperature does not coincide with some better catalyst utilization or sensibility as it can often be stated in the literature [26]. With the increase of the FC temperature from 40 to $60^{\circ} \mathrm{C}$ and at constant dew point temperature $\left(20^{\circ} \mathrm{C}\right.$ ), the ECA is reduced from 55.57 to $33.32 \mathrm{~m}^{2} \mathrm{Pt} \cdot(\mathrm{g} \mathrm{Pt})^{-1}$ (which corresponds to a drop-down of $-40 \%$ ). A diminution of the ECA from 58.98 to $40.73 \mathrm{~m}^{2}$ $\mathrm{Pt} \cdot(\mathrm{g} \mathrm{Pt})^{-1}$ (decrease of $-31 \%$ ) can also be observed when the $\mathrm{FC}$ temperature declines from 40 to $60^{\circ} \mathrm{C}$ with a constant air dew point temperature of $40^{\circ} \mathrm{C}$. The reduction of the true ECA (between Tests 4, 5 and 6, 8 on the one hand, and between Tests 1, 2, 3 and Tests 7, 9, 10 on the other hand) is mainly due to the lower RH values. When the $\mathrm{RH}$ is reduced from a low level at both electrodes $(\mathrm{RH}=31.7 \%$ for Tests 4,5$)$ to a still lower level $(\mathrm{RH}=11.7 \%$ for Tests 6,8$)$, the ECA of the cathode layer declines of $-40 \%$. However, when the RH decreases from the fully air humidified conditions $(\mathrm{RHc}=$ $100 \%$ in Tests $1,2,3$ with $\mathrm{RHa}=31.7 \%$ ) to a low humidity level at cathode (RHc $=$ $37 \%$ in Tests 7, 9, 10 with $\mathrm{RHa}=11.7 \%$ ), the reduction of the ECA (equal to $-31 \%$ ) is less than the one observed between Tests 4, 5 and Tests 6, 8. Theses comparisons suggest that the benefit of the higher operating temperature (which is often revealed in other studies [26]) is hindered in our case by too low humidity conditions that induce strong proton immovability in the catalyst layers and in the membrane.

In Fig. 1d, the peaks at the potentials ranging from $68 \mathrm{mV}$ to $470 \mathrm{mV}$ are associated with the hydrogen desorption (magenta area) / adsorption on the catalyst surface. It can be noticed that the shapes of the different voltammograms are different. Two peaks can be observed at $\mathrm{T}=40^{\circ} \mathrm{C}$ and only one peak is shown at $60^{\circ} \mathrm{C}$. The form of the adsorption / desorption area is linked to the platinum crystal surfaces. At $40^{\circ} \mathrm{C}$, the first peak in the potential range explored is close to the value of $125 \mathrm{mV}$ (versus the reference electrode) which corresponds to H-desorptions at Pt (110) plane shift. The second peak at higher voltages (about $225 \mathrm{mV}$ ) refers to H-desorptions at Pt (100) plane shift. On the contrary, only one H-adsorptions peak at Pt (100) is observed. This change implies that different mechanisms occur for hydrogen adsorption at platinum surface. However, the origin of this change is difficult to determine. Nevertheless, the recent work of [12] shows clearly that the adsorption mechanism is not influenced by the humidity of the gases, even for very low $\mathrm{RH}(4 \%)$. It could be concluded that the different processes noticed for the elevated temperature is mainly due to the temperature effect. Similar behavior was obtained for two other hydrogen and nitrogen flow rates $\left(0.5 \mathrm{~N} 1 \cdot \mathrm{min}^{-1}\right.$ and $\left.2 \mathrm{~N} 1 \cdot \mathrm{min}^{-1}\right)$ applied at both sides and shown in Fig. 2a. The influence of the flow rates on the CV and LSV graphs will be discussed in more details in Section 3.3 . 
Table 2 - List of the tests performed with the calculation of the anode and cathode Relative Humidity (RHa and RHc). Electrochemical active area (ECA) estimated through CV measurements. Crossover current, hydrogen crossover flux and internal short circuit resistance measured during LSV tests. Combinations of tests considered (X) to study the different factor impacts.

\begin{tabular}{|c|c|c|c|c|c|c|c|c|c|c|c|c|}
\hline & \multicolumn{3}{|c|}{$1,2,3$} & \multicolumn{3}{|c|}{4,5} & \multicolumn{3}{|c|}{6,8} & \multicolumn{3}{|c|}{$7,9,10$} \\
\hline \multicolumn{13}{|l|}{\begin{tabular}{|l} 
I ests Nr. \\
Factors:
\end{tabular}} \\
\hline $\mathrm{T}\left({ }^{\circ} \mathrm{C}\right)$ & \multicolumn{3}{|c|}{40} & \multicolumn{3}{|c|}{40} & \multicolumn{3}{|c|}{60} & \multicolumn{3}{|c|}{60} \\
\hline Constant $\mathrm{H}_{2} \mathrm{dwpT}\left({ }^{\circ} \mathrm{C}\right)$ & \multicolumn{3}{|c|}{20} & \multicolumn{3}{|c|}{20} & \multicolumn{3}{|c|}{20} & \multicolumn{3}{|c|}{20} \\
\hline Air dwpT $\left({ }^{\circ} \mathrm{C}\right)$ & \multicolumn{3}{|c|}{40} & \multicolumn{3}{|c|}{20} & \multicolumn{3}{|c|}{20} & \multicolumn{3}{|c|}{40} \\
\hline$\rightarrow \mathrm{H}_{2} \mathrm{RH}(\%)=\mathrm{RHa}$ & \multicolumn{3}{|c|}{31.7} & \multicolumn{3}{|c|}{31.7} & \multicolumn{3}{|c|}{11.7} & \multicolumn{3}{|c|}{11.7} \\
\hline$\rightarrow$ Air RH $(\%)=$ RHc & \multicolumn{3}{|c|}{100} & \multicolumn{3}{|c|}{31.7} & \multicolumn{3}{|c|}{11.7} & \multicolumn{3}{|c|}{37} \\
\hline \multicolumn{13}{|l|}{ CV parameter: } \\
\hline $\mathrm{H}_{2}$ and $\mathrm{N}_{2}\left(\mathrm{~N} 1 \cdot \mathrm{min}^{-1}\right)$ & 0.5 & 1 & 2 & 0.5 & 1 & 2 & 0.5 & 1 & 2 & 0.5 & 1 & 2 \\
\hline $\operatorname{ECA}\left(\mathrm{m}^{2} \mathrm{Pt} \cdot(\mathrm{g} \mathrm{Pt})^{-1}\right)$ & 66.38 & 58.98 & 53.58 & 58.80 & 55.57 & 50.54 & 35.88 & 33.32 & 30.98 & 44.75 & 40.73 & 36.19 \\
\hline \multicolumn{13}{|l|}{ LSV parameters: } \\
\hline $\begin{array}{l}\text { Crossover current } \\
\left(\mathrm{mA} \cdot \mathrm{cm}^{-2}\right)\end{array}$ & 2.40 & 2.46 & 2.42 & 2.35 & 2.35 & 2.38 & 2.55 & 2.56 & 2.55 & 2.77 & 2.71 & 2.68 \\
\hline $\begin{array}{l}\mathrm{H}_{2} \text { crossover flux (mole } \\
\mathrm{s}^{-1} \cdot \mathrm{cm}^{-2} \text { ) } \times 10^{-8}\end{array}$ & 1.25 & 1.28 & 1.26 & 1.22 & 1.22 & 1.23 & 1.32 & 1.32 & 1.32 & 1.43 & 1.40 & 1.39 \\
\hline $\begin{array}{l}\text { Internal short circuit } \\
\text { resistance }\left(\Omega \cdot \mathrm{cm}^{2}\right) \\
\end{array}$ & 225.22 & 227.27 & 225.99 & 230.42 & 231.21 & 236.69 & 220.51 & 230.15 & 225.23 & 224.72 & 218.82 & 222.97 \\
\hline \multicolumn{13}{|l|}{$\begin{array}{l}\text { CV and LSV tests } \\
\text { considered to study: }\end{array}$} \\
\hline \multirow{2}{*}{ T impact } & & & & & $\bar{X}$ & & & $\mathrm{X}$ & & & & \\
\hline & & $\mathrm{X}$ & & & & & & & & & $\mathrm{X}$ & \\
\hline \multirow{2}{*}{ Air dwpT impact } & & $\mathrm{X}$ & & & $\mathrm{X}$ & & & & & & & \\
\hline & & & & & & & & $\mathrm{X}$ & & & $\mathrm{X}$ & \\
\hline
\end{tabular}

$E C A\left(\mathrm{~cm}^{2} \mathrm{Pt} \cdot(\mathrm{g} \mathrm{Pt})^{-1}\right)$ is calculated by applying Eq. (1):

$$
E C A=\frac{C h \arg e}{210 \times 10^{-3} \times \text { Pt loading }}
$$

Where:

Charge represents the charge $\left(\mathrm{mC} \cdot \mathrm{cm}^{-2}\right)$ associated to the hydrogen adsorption / desorption,

Pt loading is the loading of platinum at the studied electrode $\left(\mathrm{g} \mathrm{Pt} \cdot \mathrm{cm}^{-2} \mathrm{Pt}\right)$,

$210 \cdot 10^{-3}$ is the hydrogen adsorption / desorption charge $\left(\mathrm{mC} \cdot \mathrm{cm}^{-2} \mathrm{Pt}\right)$ on a smooth $\mathrm{Pt}$ electrode.

\section{- LSV voltammogram results:}

Crossover of hydrogen from anode to cathode by permeation through the membrane degrades the performance of the cell by reducing the cell OCV [27]. Referred as fuel crossover, the same phenomenon can occur for oxygen. At the beginning of life, the 
"internal leakage" flow of hydrogen molecules is small but it exists. A typical value for the crossover current density in a "safe" low temperature cell operated in conventional conditions is $2-3 \mathrm{~mA} \cdot \mathrm{cm}^{-2}$. This imperfection of the membrane may lead to the formation of $\mathrm{OH}^{\cdot}$ radical ions that react with air, resulting in the degradation of the membrane permeability to hydrogen and oxygen molecules. Fuel crossover is also responsible of fuel efficiency reduction and cathode potential depression [27]. A direct conduction of electrons between each electrode also exists. This permeation of electrons is also a source of losses [28]. Referred to as internal short circuit, this phenomenon occurs if small portions of an electrode come into contact with another contact due to membrane thinning [29]. The presence of an internal short circuit is characterized by a positive slope above an applied potential of $0.25 \mathrm{~V}$.

As depicted in Fig. 1e and as tabulated in Table 2, the temperature impacts slightly the reactant crossover through the membrane. To make this statement, Tests 4,5 can be compared to Tests 6,8 (with flows of $1 \mathrm{Nl} \cdot \mathrm{min}^{-1}$ ): the crossover current increases from 2.35 to $2.56 \mathrm{~mA} \cdot \mathrm{cm}^{-2}(+8.9 \%)$ when the $\mathrm{FC}$ temperature rises from 40 to $60^{\circ} \mathrm{C}$ (with a constant air dew point temperature of $20^{\circ} \mathrm{C}$ ). The same conclusion can be made by considering Tests 1, 2, 3 on the one hand and Tests 7, 9, 10 on the other hand (Air dwpT $\left.=40^{\circ} \mathrm{C}\right)$. In this case, the crossover current increases from 2.46 to $2.71 \mathrm{~mA} \cdot \mathrm{cm}^{-2}$ $(+10.2 \%)$ when the flows equal $1 \mathrm{Nl} \cdot \mathrm{min}^{-1}$. This increase of the crossover current as a function of the cell temperature might be due to a mechanical stress of the membrane (expansion/contraction phenomena) which would be larger at higher cell temperatures and would allow hydrogen molecules to permeate more easily through the membrane pores $[22,30]$. Internal short circuit resistance does not show any strong dependence with the cell temperature when RH is low: an insignificant decrease (less than $0.5 \%$ ) is observed between Tests 4, 5 and Tests 6, 8. On the contrary, when the RH is high, a moderate diminution $(-1.5 \%)$ of the internal short circuit resistance is observed when temperature raises from $40^{\circ} \mathrm{C}$ (Tests $1,2,3$ ) to $60^{\circ} \mathrm{C}$ (Tests $7,9,10$ ). The same conclusions can be done for the other two flow rates $\left(0.5 \mathrm{Nl} \cdot \mathrm{min}^{-1}\right.$ and $\left.2 \mathrm{Nl} \cdot \mathrm{min}^{-1}\right)$ at both sides (Fig. 2b).

The hydrogen crossover flux $N_{H 2}\left(\right.$ mole $\left.\cdot \mathrm{s} \cdot \mathrm{cm}^{-2}\right)$ is calculated by the Faraday law (Eq. 2):

$$
N_{H 2}=\frac{i_{l}}{n \times F}
$$

Where:

$I_{l}$ is the maximum current value $\left(\mathrm{A} \cdot \mathrm{cm}^{-2}\right)$ for the potential ranging from 0 to $0.25 \mathrm{~V}$, $n$ is the number of electrons per reaction (here, $n=2$ ),

$F$ is the Faraday constant $\left(\mathrm{C} \cdot \mathrm{mole}^{-1}\right)$.

Internal short circuit resistance is calculated from the inverse of the slope in the linear region $0.4-0.6 \mathrm{~V}$. 


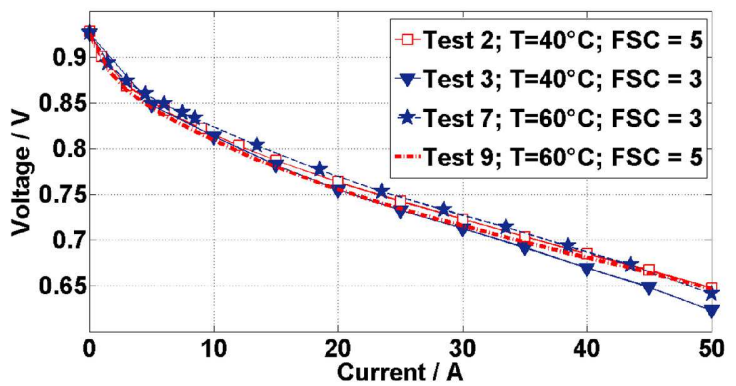

a)

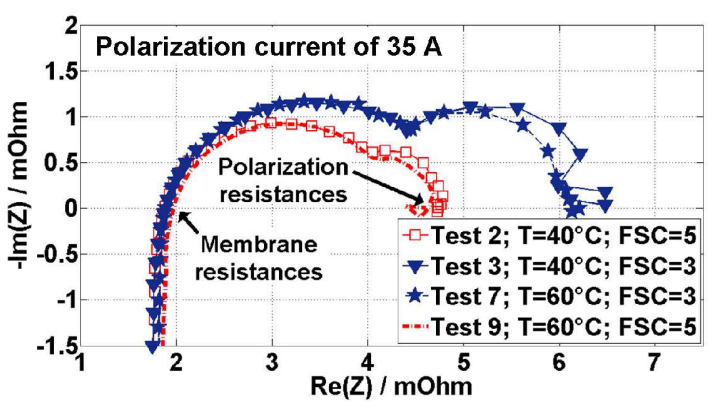

b)

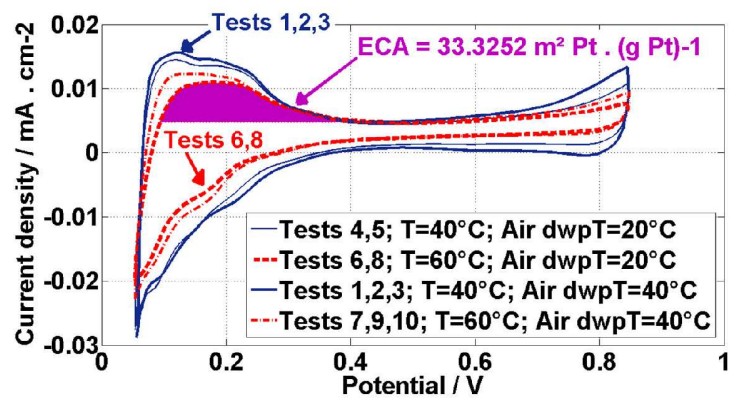

d)

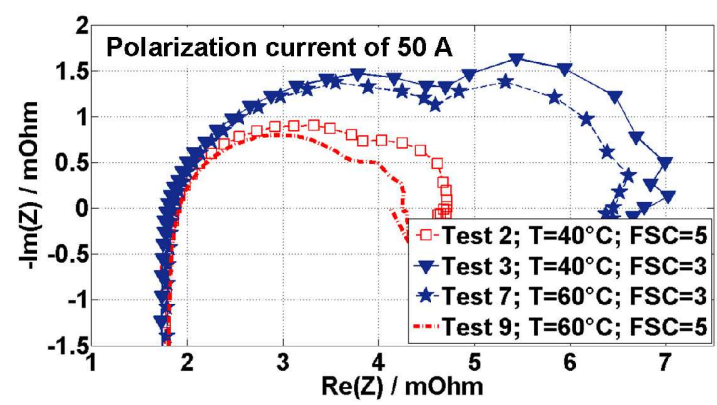

c)

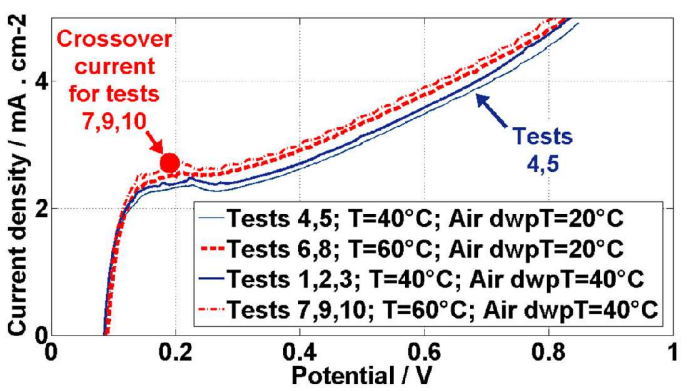

e)

Fig. 1 - Effects of operating temperature $(\mathrm{T})$ on the FC performances.

a) Polarization curves for different $\mathrm{T}$ (air dew point $=\mathrm{Air} \operatorname{dwpT}=40^{\circ} \mathrm{C}$ and $\mathrm{FSA}=2$ ).

b) Impedance spectra for different $\mathrm{T}$ (air dew point $=40^{\circ} \mathrm{C}$ and $\mathrm{FSA}=2$ ) at $35 \mathrm{~A}$.

c) Impedance spectra for different $\mathrm{T}$ (air dew point $=40^{\circ} \mathrm{C}$ and $\mathrm{FSA}=2$ ) at $50 \mathrm{~A}$.

d) Cyclic voltammograms for different $\mathrm{T}$ (hydrogen and nitrogen flows of $1 \mathrm{Nl} \cdot \mathrm{min}^{-1}$ ).

e) Linear sweep voltammograms for different $\mathrm{T}$ (hydrogen and nitrogen flows of $1 \mathrm{Nl} \cdot \mathrm{min}^{-1}$ ).

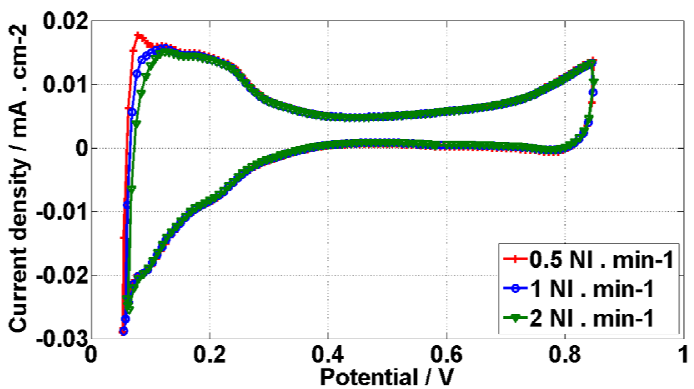

a)

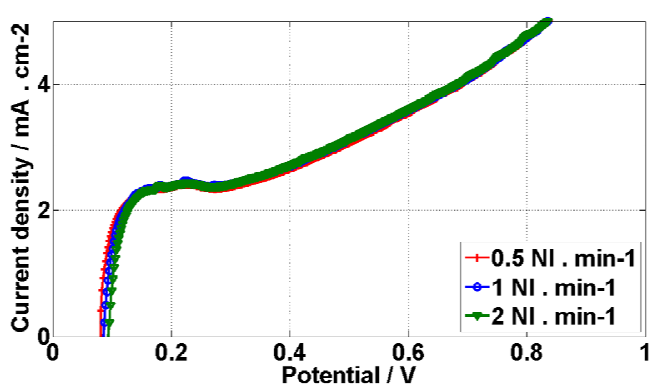

b)

Fig. 2 - Example of hydrogen and nitrogen flow rate effects on the CV (Fig. 2a) and LSV (Fig. 2b) diagrams (case: Tests 1, 2, 3). 


\subsection{Effects of air dew point temperature on the FC performances}

PEMFCs equipped with perfluorosulfonic membranes usually require some external humidification of the reactants in order to maintain sufficient water contents in the membranes and to insure the proton conductivity. In [31], the authors mention that the membrane resistance at $25 \% \mathrm{RH}$ (on both sides) is about five times higher than the resistance at $100 \%$ RH. Drying the cathode, with low cathode RH and low current density, can lead to the increase of the ionic resistance in the catalyst layer, but also to the increase of the charge transfer and mass transport resistances [12]. The same phenomena have been related in [31]. H.-T. Kim et al. have also noticed a slow down in the oxygen-reduction reactions due to the reduction of the ECA [12]. The ECA was reduced because the proton access to the catalyst sites was limited by the ionomer. In [32], the authors have demonstrated that the humidity level at anode and cathode is dependent on the operating voltage value. For low operating voltages, the cell performance is mainly dependent on the cathode mass transport limitations due to the effect of liquid water blockage. In more vivid words, at low operating voltages for both flow fields, the cell performance decreases as RHc increases. However, when the FC is operated at higher voltages, a higher RHc increases the water concentration on the cathode side and the back-diffusion of water, which provides more water for the membrane, resulting in better cell performance. In their work [33], F. Urbani et al. have remarked that the cathode $\mathrm{RH}$ has a stronger influence on the cell performance decay and lifetime compared to the anode one.

\section{- Polarization curve results:}

According to Table 1, the effect of air dew point temperature in the U-I and EIS measurements can be determined through two different experiment comparisons: Test 3 with Test 5, and Test 8 with Test 9 .

In Fig. 3a, the effect of air dew point temperature seems to be particularly significant in the conditions of high $\mathrm{FC}$ operating temperature $\left(\mathrm{T}=60^{\circ} \mathrm{C}\right.$; Tests 8 and 9) and low currents $(<35 \mathrm{~A})$ for which ones more pronounced drying phenomena can occur. The drying effect due to higher cell temperature and low humidity conditions is compensated by water production for currents exceeding $35 \mathrm{~A}$. With regard to Tests 3 and 5 (FC temperature of $40^{\circ} \mathrm{C}$ ), higher air dew point temperature (leading to higher cathodic $\mathrm{RH}$ ) induces a minor decay of the FC electrical performances over the full current range. This can be attributed to the effects of the low air flow values $(\mathrm{FSC}=3)$ and $\mathrm{FC}$ temperature $\left(40^{\circ} \mathrm{C}\right)$ which lead to an insufficient water removal at $\mathrm{FC}$ outlet (light flooding process).

\section{- Impedancemetry results:}

In Fig. 3b, a higher ionic electrolyte resistance value can be observed when the difference between the air dew point temperature and the FC temperature is large (this is the case between Tests 8 and 9). The highest value of the cell resistance is obtained for Test 8 when elevated cathodic flow rate $(\mathrm{FSC}=5)$ and cell temperature $\left(\mathrm{T}=60^{\circ} \mathrm{C}\right)$ are combined with low air dew point temperatures (Air dwpT $=20^{\circ} \mathrm{C}$ ). This typical behavior is often observed for perfluorinated ionomer membranes [31,34]. As shown in Table 1, the highest ionic resistance measured in Test $8(2.17 \mathrm{~m} \Omega)$ is obtained with an increase close to $11 \%$ in comparison with the value of Test $9(1.96 \mathrm{~m} \Omega)$ obtained at Air dwpT $=40^{\circ} \mathrm{C}$. $\mathrm{FC}$ overall performances can be deduced from the polarization 
resistance; a higher value is related to larger global losses. Polarization resistance is notably influenced by mass transports. The impedance spectra of Tests 8 and 9 (recorded for $\mathrm{T}=60^{\circ} \mathrm{C}$ and displayed in Fig. 3b) show some low frequency arcs (linked with gas diffusion phenomena) which have small amplitudes compared to those of the high frequency loops (corresponding to charge transfers). With regard to Tests 3 and 5 performed at low cell temperature $\left(\mathrm{T}=40^{\circ} \mathrm{C}\right)$, an excessive water presence in the GDLs combined with low air flows $(\mathrm{FSC}=3)$ increases slightly the size of the second arc circle (low frequency arc) related to the diffusion of species. The studies of the impedance results obtained at 35 and 50 A lead to similar conclusions. However, the drying phenomena observed at $35 \mathrm{~A}$ is more exacerbated at $50 \mathrm{~A}$. The electrolyte resistance value measured in Test 9 is reduced to $1.92 \mathrm{~m} \Omega$ whereas the membrane resistance of Test 8 increases up to $2.24 \mathrm{~m} \Omega(+16.7 \%)$. This increase of the membrane resistance, which is higher in comparison with the results obtained at $35 \mathrm{~A}$, indicates clearly that the excess of water production is not sufficient to correctly humidified the dried cell. At lower cell temperature, a higher air dew point temperature coupled with a high cathode flow rate contributes to slight better performances.

\section{- CV voltammogram results:}

According to Table 2, in order to evaluate the impact of the air dew point temperature, Tests 4, 5 can be compared to Tests 1,2, 3 while Tests 6,8 can be evaluated against Tests $7,9,10$.

The tests recorded for a cell temperature of $40^{\circ} \mathrm{C}$ can be first considered (Fig. 1d). The values of the active surface areas computed for Tests 4, 5 (performed for Air dwpT = $20^{\circ} \mathrm{C}$ ) are only a littler lower than the values related to Tests 1, 2, 3 (performed for Air $\mathrm{dwpT}=40^{\circ} \mathrm{C}$ ). The rise of the air dew point leads to a $+6.1 \%$ increase of the ECA. At higher cell temperature $\left(\mathrm{T}=60^{\circ} \mathrm{C}\right)$, the increase of the air dew point from $20^{\circ} \mathrm{C}$ (Tests $6,8)$ to $40^{\circ} \mathrm{C}$ (Tests $7,9,10$ ) leads to a more significant enhancement of the ECA (+ $22.2 \%$ ). At higher RH values, both Pt-oxidation and Pt-oxide-reduction currents in the range $0.7-0.85 \mathrm{~V}$ are strong; indicating that the water concentration near the Pt surface is high. $\mathrm{RH}$ at cathode appears to have a large impact on the active surface area (ECA value). In [35], the authors affirm that a too low humidity causes a poor catalyst utilization. In fact, this effect is caused by the proton immovability in the catalyst layer, due to the dehydration effect at low humidity. This immovability of protons does not allow electrochemical reactions to occur. The same remarks could be done for two other flow rates $\left(0.5 \mathrm{Nl} \cdot \mathrm{min}^{-1}\right.$ and $\left.2 \mathrm{Nl} \cdot \mathrm{min}^{-1}\right)$ at both sides.

\section{- LSV voltammogram results:}

As shown in Fig. 1e, the air dew point temperature is also a factor which impacts the crossover current and the internal short circuit current. An increase of the air dew point temperature (from 20 to $40^{\circ} \mathrm{C}$ ) induces a little drop of the crossover current value, as listed in Table $2\left(+4.7 \%\right.$ for Tests $1,2,3$ and 4,5 performed at $40^{\circ} \mathrm{C}$, and $+5.9 \%$ for Tests 6,8 and $7,9,10$ recorded at $60^{\circ} \mathrm{C}$ ) for $1 \mathrm{Nl} \cdot \mathrm{min}^{-1}$ flow rates at both sides. The expansion of the membrane due to the higher water content can possibly increase the pore sizes of the membrane [22]. Indeed, perfluorosulfonic membrane can be considered as a sponge from a dynamical fluidic aspect. In fact, the important water content inside the electrolyte involves a change in the geometrical size of the membrane, particularly in its thickness. A larger pore size facilitates the permeation of the hydrogen molecules through the membrane. Some similar conclusions can be done 
for the two other flow rates $\left(0.5 \mathrm{Nl} \cdot \mathrm{min}^{-1}\right.$ and $\left.2 \mathrm{Nl} \cdot \mathrm{min}^{-1}\right)$, even if the flow rate values influence the crossover current only moderately. In addition, it can be noticed that the internal short circuit resistance does not show any strong dependence with the air dew point temperature.

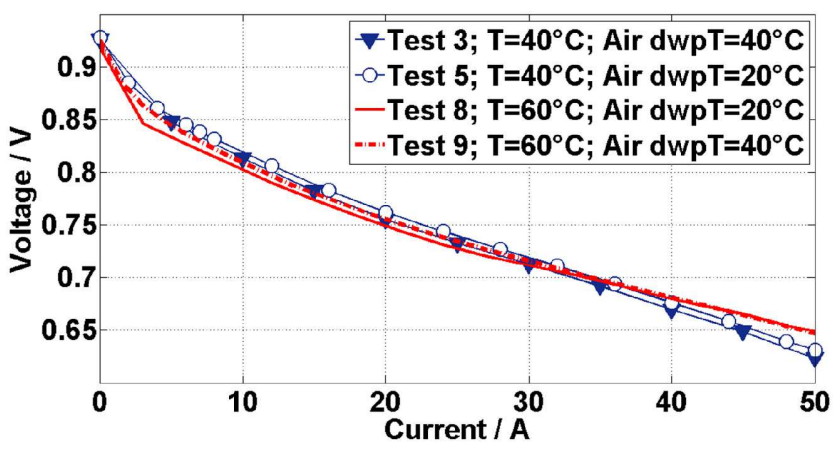

a)

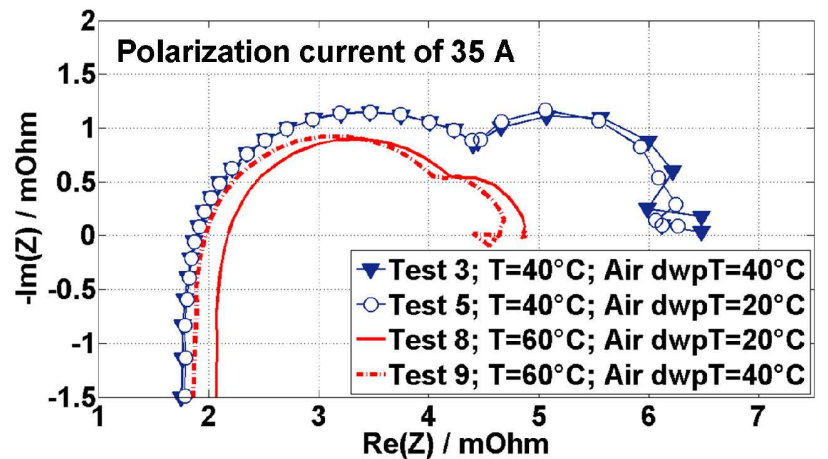

b)

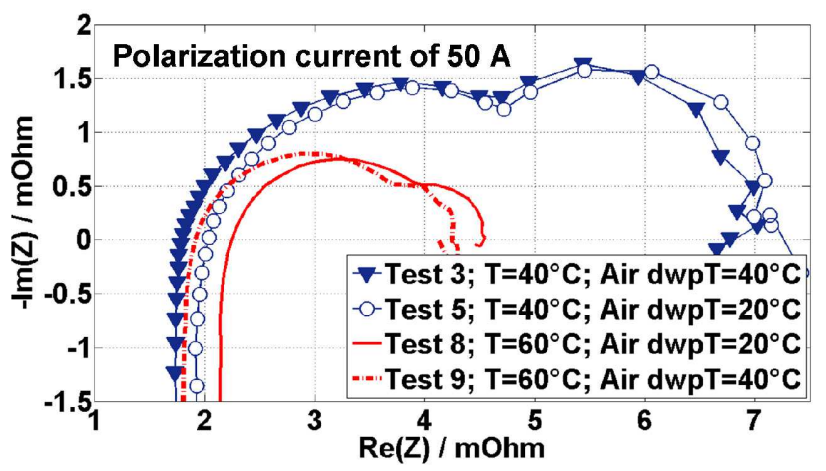

c)

Fig. 3 - Effects of air dew point temperature (Air dwpT) on the $\mathrm{FC}$ performances.

a) Polarization curves recorded for different air dew points (FSA $=2$ and $\mathrm{FSC}=3$ for operating temperature $\left.(\mathrm{T})=40^{\circ} \mathrm{C}\right)\left(\mathrm{FSA}=2\right.$ and $\mathrm{FSC}=5$ for $\left.\mathrm{T}=60^{\circ} \mathrm{C}\right)$.

b) Impedance spectra at $35 \mathrm{~A}$ for different air dew points ( $\mathrm{FSA}=2$ and $\mathrm{FSC}=3$ for $\mathrm{T}=$ $\left.40^{\circ} \mathrm{C}\right)\left(\mathrm{FSA}=2\right.$ and $\mathrm{FSC}=5$ for $\left.\mathrm{T}=60^{\circ} \mathrm{C}\right)$ at $35 \mathrm{~A}$.

c) Impedance spectra at $50 \mathrm{~A}$ for different air dew points $(\mathrm{FSA}=2$ and $\mathrm{FSC}=3$ for $\mathrm{T}=$ $\left.40^{\circ} \mathrm{C}\right)\left(\mathrm{FSA}=2\right.$ and $\mathrm{FSC}=5$ for $\left.\mathrm{T}=60^{\circ} \mathrm{C}\right)$ at $35 \mathrm{~A}$. 


\subsection{Effects of anode stoichiometry rates on the FC performances}

Hydrogen utilization is an important criterion for FC stack designer. A too low hydrogen flow can induce hydrogen starvation involving an oxidation of platinum or platinum / ruthenium at anode (dissolution, sintering phenomena) [36]. On the contrary, a high flow rate of hydrogen will improve the performance to the detriment of the efficiency linked with the fuel consumption. In [23], J-H. Jang et al. have demonstrated that the effects of anode gas stoichiometric ratio on the performance of individual cells and stack do not lead to a visible difference with the increase in anode gas stoichoimetric ratio. This is owing to the fact that a sufficient amount of fuel was supplied to the tested FC assembly for the considered parameter levels.

\section{- Polarization curve results:}

To examine the influence of FSA on the U-I (and EIS) curves, Test $1(\mathrm{FSA}=3)$ can be compared to Test 3 (FSA = 2). Besides, the pair of Tests 9 and 10 can also be considered (FSA $=2$ and 3 respectively).

In Fig. 4a, the same static performances are measured for Tests 9 and 10 both performed for a FC temperature of $60^{\circ} \mathrm{C}$. No evidence of FSA influence is shown and in these two cases, a good diffusivity of hydrogen up to the active sites is achieved. In contrast, at a cell temperature of $40^{\circ} \mathrm{C}$, a noticeable difference between Tests 1 and 3 is measured especially in the diffusive region (gap of about $20 \mathrm{mV}$ ). However, the drop-down of the performances with a higher FSA can possibly be explained by a drying process at the anode due to an excess of water removal.

\section{- Impedancemetry results:}

The impedance spectra recorded at 35 A (Fig. 4b) and the related results displayed in Table 1 confirm the poor effect of the FSA increase over the global FC performances (linked to the polarization resistance values). Tests 1 and 3 have some comparable polarization resistances. Tests 9 and 10 show also some equivalent polarization resistance values. However, for a cell temperature level of $60^{\circ} \mathrm{C}$, which corresponds in fact to the upper bound of the nominal temperature range (see section 2.1), a remarkable increase of the electrolyte resistance $(+15.9 \%)$ can be noticed when FSA value is equal to 3 (Test 10). The water balance and management in the membrane are impacted by the stoichiometry rate factors. The electrolyte resistance value depends mainly on the water amount inside the polymer but also on the spatial distribution of the water content in the membrane. Due to the water production at cathode, the membrane region near to the anode (fed by low humidified hydrogen) might be not sufficiently hydrated [37]. Considering Tests 9 and 10, a slight increase of the dry hydrogen flow value reduces strongly the water content at the interfacial anode/membrane region. Similar behavior was observed for the impedance spectra recorded with a 50 A polarization current (Fig. $4 \mathrm{c})$. However, for this higher current value and for the lowest $\mathrm{FC}$ temperature $\left(\mathrm{T}=40^{\circ} \mathrm{C}\right.$ in Tests 1 and 3), the low frequency loops linked to the diffusion phenomena have some larger sizes.

The electrolyte resistance of the investigated FC (equipped with its current GDL and graphite plate technology / design) has a non linear behavior versus reactant humidification, flow rates and cell temperature, especially in the range $50-65^{\circ} \mathrm{C}$. These observations were made during several tests performed in the lab on similar FC 
assemblies. Some parts of the experiment results are reported in the references $[38,39]$. For the FC temperature ranging between 40 and about $55-60^{\circ} \mathrm{C}$ and for the same reactant humidity rates, the FC shows better performances with higher FSA / FSC (typically $2 / 5$ or $3 / 5$ ). In these conditions, a better draining of the water out of the cell is ensured and in the same time, no decrease of the electrolyte resistance linked to a membrane drying is observed. However, for temperature levels higher than $60^{\circ} \mathrm{C}$, a reactant feeding with higher FSA / FSC rates lead to worse performances and lower FSA / FSC (e.g. 2 / 4 or 2/3) can be preferred, mainly to avoid the drying of the MEAs.

\section{- CV voltammogram results:}

In Fig. 4d, the CV voltammograms indicate that higher flow rates lead to worse catalyst utilization (in the experimental domain explored). The enhancement of the true ECA is inversely proportional to the flow rate values. At $0.5 \mathrm{Nl} \cdot \mathrm{min}^{-1}$, the ECA is increased by $+5.8 \%$ and reduced by $-10 \%$ at $2 \mathrm{Nl} \cdot \mathrm{min}^{-1}$ in comparison with the ECA value noticed at $1 \mathrm{~N} l \cdot \mathrm{min}^{-1}$ (the values are displayed in the column of Tests 4 and 5 in Table 2). It is easy to understand that the higher flow rates increase the water removal out of the cell, which reduces the water content inside the cathode compartment. As mentioned in Section 3.2, a reduction of the humidity usually induces a diminution of the ECA. At first sight, the shapes of the curves can be considered as similar, which implies that the mechanisms of desorption are the same ones. Two peaks reflecting the desorption of hydrogen molecules can be distinguished. Nevertheless, the diagram related to the lowest flow $\left(0.5 \mathrm{Nl} \cdot \mathrm{min}^{-1}\right)$ presents a first peak that is more marked if compared to the other flow values. Consequently, the ECA value is higher than the other ones, as it can be verified in Table 2. A lower ECA value induces worse overall electrical performances. The lower ECA values obtained with the higher flow rates are in agreement with the cell performances measured in Fig. 4a.

\section{- LSV voltammogram results:}

As shown in Table 2 and Fig. 4e, crossover current values and internal short circuit resistances do not show any strong variability. This invariance suggests that the membrane does not present any deterioration of its mechanical structure and remains impermeable to hydrogen molecules [29]. 


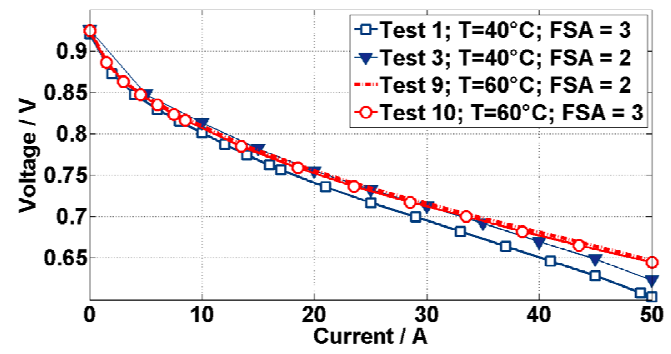

a)

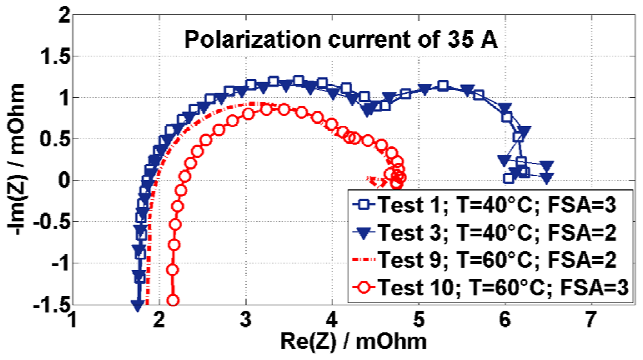

b)

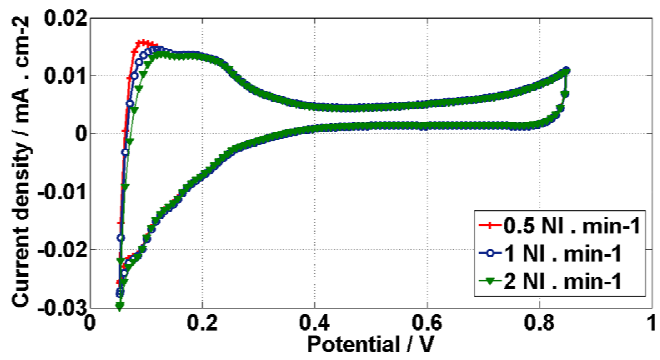

d)

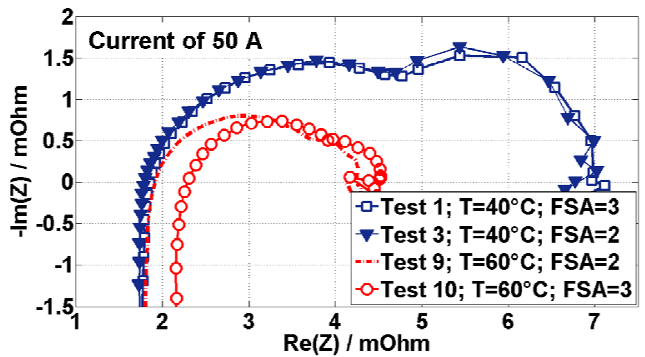

c)

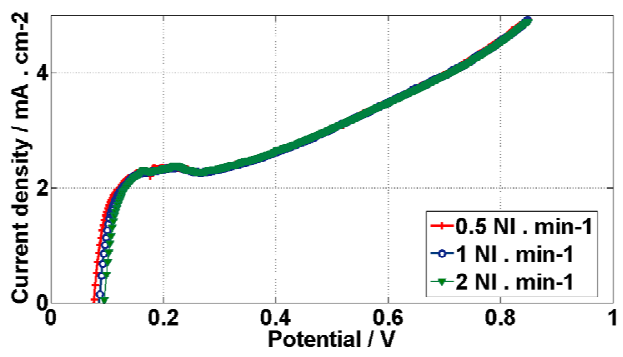

e)

Fig. 4 - Effects of anode flow rate on the FC performances.

a) Polarization curves for different FSA with air dew point $=40^{\circ} \mathrm{C}(\mathrm{FSC}=3$ for operating temperature $\left.\mathrm{T}=40^{\circ} \mathrm{C}\right)\left(\mathrm{FSC}=5\right.$ for $\left.\mathrm{T}=60^{\circ} \mathrm{C}\right)$.

b) Impedance spectra for different FSA with air dew point $=40^{\circ} \mathrm{C}(\mathrm{FSC}=3$ for $\mathrm{T}=$ $\left.40^{\circ} \mathrm{C}\right)\left(\mathrm{FSC}=5\right.$ for $\left.\mathrm{T}=60^{\circ} \mathrm{C}\right)$ at $35 \mathrm{~A}$.

c) Impedance spectra for different FSA with air dew point $=40^{\circ} \mathrm{C}(\mathrm{FSC}=3$ for $\mathrm{T}=$ $\left.40^{\circ} \mathrm{C}\right)\left(\mathrm{FSC}=5\right.$ for $\left.\mathrm{T}=60^{\circ} \mathrm{C}\right)$ at $50 \mathrm{~A}$.

d) Cyclic voltammograms for different hydrogen and nitrogen flow rates $\left(\mathrm{T}=40^{\circ} \mathrm{C}\right.$, air dew point $=20^{\circ} \mathrm{C}, \mathrm{FSA}=\mathrm{FSC}$ for each test).

e) Linear sweep voltammograms for different hydrogen and nitrogen flow rates $(\mathrm{T}=$ $40^{\circ} \mathrm{C}$, air dew point $=20^{\circ} \mathrm{C}, \mathrm{FSA}=\mathrm{FSC}$ for each test).

\subsection{Effects of cathode stoichiometry rates on the FC performances}

From the FC researcher point of view, the electrochemical activity of FC cathode is probably the most interesting one due to the sluggish kinetics of the Oxygen Reduction Reaction (ORR) [40]. A lowest air supply at cathode can cause some air starvation problems with the same consequences: platinum dissolution or sintering [41]. To reduce the losses at cathode, this flow rate is increased with the aim to boost the cathodic catalyst utilization, but this improvement of performance induces some energy losses in ancillary sections like air-compressor [42]. In [23], J-H. Jang et al. have observed that 
the performances of each cell in the stack are improved when a higher cathode gas stoichiometric ratio is used. The main reason of the performance increase is linked to the stack design and to the gas supply inlet location versus cell position. The authors have noticed only an enhancement of the performances for the cells located near the center of the stack where the hydrogen molar fraction is insufficient. However, the overall performance did not change when an apparent level of cathode stoichoimetry was reached. The same conclusions have been made in [24]. The authors have proposed one explanation for the enhancement of the electrical performances caused by an increase of the air flow rate. Lower cell performances are obtained with low FSC to the incomplete consumption of the anode hydrogen. Nevertheless, when the amount of oxygen supplied at the cathode is adequate to completely consume hydrogen at the anode, increasing oxygen flow rate will not enhance the cell performance at a constant hydrogen flow rate.

\section{- Polarization curve results:}

Let us consider Fig. 1a again. For a FC temperature of $40^{\circ} \mathrm{C}$ (Tests 2 and 3 with $\mathrm{FSC}=$ 5 and 3 respectively), the benefit of a higher cathode flow rate is clearly visible, in particular in the diffusive region of the related U-I curves. An increase of the cell voltage as a function of the load current can be observed. As an example, a gap of +25 $\mathrm{mV}$ can be noticed at 50 A. This result is in adequacy with the work presented in $[23,24]$. The origin of the performance enhancement could also be explained by the process described in [24]. However, when the cell temperature is higher (Tests 7 and 9 at $\mathrm{T}=60^{\circ} \mathrm{C}$ with $\mathrm{FSC}=3$ and 5 respectively), the limited humidity hinders the improvement of performance caused by the higher cathode stoichiometry. For low currents (in the $0-25 \mathrm{~A}$ range), the better performances are obtained for the lowest FSC. This is the consequence of a partial membrane dehydration induced by an insufficient water production and low humidified gases at both electrodes. On the other hand, for currents ranging from 25 to $50 \mathrm{~A}$, the FSC effect cannot be hindered by the drying phenomena noticed at lower currents.

\section{- Impedancemetry results:}

As shown in Fig. $1 \mathrm{~b}$ and $1 \mathrm{c}$, the impact of the FC operation with higher FSC is confirmed by the impedance graphs. For a FC temperature of $40^{\circ} \mathrm{C}$ (Tests 2 and 3 with $\mathrm{FSC}=5$ and 3 respectively), the polarization resistances measured for load currents equal to 35 and $50 \mathrm{~A}$ decrease of -27 and $-30.9 \%$ respectively with a higher FSC. At a cell temperature of $60^{\circ} \mathrm{C}$ (Tests 7 and 9), the FSC impact on the polarization resistance is similar. With a higher FSC, the polarization resistances drop down with -24.3 and $34.1 \%$ for load currents equal to 35 and $50 \mathrm{~A}$. So, in all the cases, increasing the FSC leads to higher FC performances.

Usually, a higher oxidant flow rate reduces the mass transport resistance. As expected, in Fig. 1b and 1c, the sizes of the diffusion loops (low frequency arcs) decrease when the oxidant flows increase whatever the cell temperature and the humidity level. Charge transfer is also directly influenced by the FSC ratio. A high value of FSC contributes to increase the transfer of charges at the electrodes. If FSC has a predominant and positive effect on the FC behavior through enhanced mass transport and charge transfer, the reactant streams have to remain sufficiently hydrated in order to prevent membrane failure $[43,44]$. No large change in the membrane conductivity was observed in the various experiments conducted. At $\mathrm{T}=40^{\circ} \mathrm{C}$ and with FSC increasing from 3 (Test 3) to 
5 (Test 2), the variation of the membrane resistance was about $-0.5 \%$ and $+5 \%$ for currents equal to 35 and $50 \mathrm{~A}$. At $\mathrm{T}=60^{\circ} \mathrm{C}$, with the higher air flows, the variation of the membrane resistance was about $+4.2 \%$ and $+2.7 \%$ (Tests 7 and 9 ).

\section{Conclusions}

A single PEMFC has been operated by varying the cell temperature, the air dew point temperature and the anode/cathode stoichiometry rates with the objective to identify the parameters and combinations of factors affecting the performance. The FC characterizations tests have been conducted using in-situ electrochemical methods based on FC current and voltage signal analysis: polarization curves, EIS measurements, cyclic and linear sweep voltammetry tests. We can also point out the fact that some of the FC experiments were performed with low humidified reactants $(\mathrm{RH}=11.7 \%)$.

The main conclusions that can be made in the experimental domain explored are the following ones.

- The benefit of a higher cell temperature on the global FC performances was observed through the polarization curves. The EIS, CV and LSV test results were useful to discriminate the different loss sources. Using EIS, it was shown that higher temperature participates to a better gas diffusion in the $\mathrm{FC}$ (making easier the water removal). A slight membrane drying was also detected at a cell temperature of $60^{\circ} \mathrm{C}$, with $\mathrm{FSC}=5$ and relatively low humidified reactants $(\mathrm{RHa}=11.7 \%$ and $\mathrm{RHC}=37 \%)$. The ECA was found as mainly impacted by the $\mathrm{RH}$ in the cell (thus, indirectly by the cell temperature). An increase of the temperature from 40 to $60^{\circ} \mathrm{C}$ led to a significant diminution of the ECA ( $-31 \%$ to $-40 \%$ following the other test conditions) and to higher crossover rates (about $+10 \%)$. The temperature raise has only a weak effect $(<2 \%)$ on the internal short circuit resistance.

- The air dew point temperature had a significant effect on the $\mathrm{FC}$ overall performances (measured by the polarization curves) in the conditions of higher temperature $\left(60^{\circ} \mathrm{C}\right)$ and low current density $\left(<0.35 \mathrm{~A} \cdot \mathrm{cm}^{-2}\right)$ for which ones drying phenomena can occur. An increase of the air dew point (from $20^{\circ} \mathrm{C}$ to $40^{\circ} \mathrm{C}$ ) at a cell temperature of $40^{\circ} \mathrm{C}$ and with $\mathrm{FSC}=3$ caused a slight decay of the voltage. The difficult mass transfer and water removal out of the cell were highlighted by EIS measurements, as well as the expected strong dependence of the electrolyte resistance on the air humidity. The highest membrane resistance $\left(229 \mathrm{~m} \Omega \cdot \mathrm{cm}^{2}\right)$ was measured for the lowest air dew point coupled with the highest cell temperature and stoichiometry rates. A higher air dew point induced a drop of the ECA (up to $+22 \%$ ), suggesting that a higher humidity in the cell improves the catalyst utilization, and led to a small increase $(+5 \%)$ of the crossover current.

- Increasing the stoichiometry rates generally improved the mass transport especially when the humidity level in the cell was elevated. However, higher flow rates (FSA $=3$ and FSC $=5)$ combined with higher cell temperature $\left(60^{\circ} \mathrm{C}\right)$ and low humidified gases caused a cell drying. In the CV measurements, the lower the flow values were, the larger the ECA. This is likely to be explained by the fact that a higher humidity in the cell was achieved with lower flows and that the higher humidity caused better catalyst utilization.

With regard to the experimental domain explored, the choice of a parameter set allowing simultaneously maximum output voltages and limited cell material 
degradation appears to be difficult. For instance, higher FC temperature and cathode stoichiometry rate can induce significant electrical efficiency benefit, notably by increasing the reversible potential and the kinetics of the ORR. However, increasing the cell temperature can also gradually dry the membrane and induce a membrane failure in a more or less long-term period. LSV has also shown that elevated FC temperature and RHc can also accelerate membrane degradation (slightly higher fuel crossover rate was detected) and reduce lifetime expectancy.

\section{References}

1 S. D. Knights, K. M. Colbow, J. St-Pierre, D. P. Wilkinson, Ageing mechanisms and lifetime of PEFC and DMFC, J. Power Sources 127 (2004) 127-134.

2 B. Wahdame, D. Candusso, X. François, F. Harel, M.-C. Péra, D. Hissel, J.-M. Kauffmann, Comparison between two PEM fuel cell durability tests performed at constant current and under solicitations linked to transport mission profile, Int. J. Hydrogen Energy 32 (2007) 4523-4536.

3 F. Harel, X. François, D. Candusso, M.-C. Péra, D. Hissel, J.-M. Kauffmann, PEMFC durability test under specific dynamical current solicitation linked to vehicle road cycle, Fuel cells from fundamental to systems 7 (2007) 142-152.

4 J. Chen, B. Zhou, Diagnosis of PEM fuel cell stack dynamic behaviors, J. Power Sources 177 (2008) 83-95.

5 J. Wu, X. Z. Yuan, H. Wang, M. Blanco, J.J. Martin, J. Zhang, Diagnostic tools in PEM fuel cell research: Part I Electrochemical techniques, Int. J. Hydrogen Energy 33 (2008) 1735-1746.

6 J. Wu, X. Z. Yuan, H. Wang, M. Blanco, J.J. Martin, J. Zhang, Diagnostic tools in PEM fuel cell research: Part II physical/chemical methods, Int. J. Hydrogen Energy 33 (2008) 1747-1757.

7 D. Candusso, J.-P. Poirot-Crouvezier, B. Bador, E. Rullière, R. Soulier, J.-Y. Voyant, Determination of current density distribution in proton exchange membrane fuel cells, Eur Phys J Appl Phys 25 (2004) 67-74.

8 T. Kadyk, R. Hanke-Rauschenbach, K. Sundmacher, Nonlinear Frequency Response Analysis of PEM Fuel Cells for Diagnosis of Dehydration, Flooding and CO Poisoning, J. Electroanalytical Chemistry (2009).

9 G. Tian, S. Wasterlain, I. Endichi, D. Candusso, F. Harel, X. François, M.-C. Péra, D. Hissel, J.-M. Kauffmann, Diagnosis methods dedicated to the localisation of failed cells within PEMFC stacks, J. Power Sources 182 (2008) 449-461.

10 S. Litster, J. G. Santiago, Dry gas operation of proton exchange membrane fuel cells with parallel channels: Non-porous versus porous plates, J. Power Sources 188 (2009) 82-88.

11 M. Hinaje, I. Sadli, J.-P. Martin, P. Thounthong, S. Raël, B. Davat, Online humidification diagnosis of a PEMFC using a static DC-DC converter, Int. J. Hydrogen Energy 34 (2009) 2718-2723.

12 H.-T. Kim, K.-Y. Song, T.V. Reshetenko, S.-I. Han, T.-Y. Kim, S.-Y. Cho, M.K. Min, G.-S. Chai, S.-C. Shin, Electrochemical analysis of polymer electrolyte membrane fuel cell operated with dry-air feed, J. Power Sources (2009).

13 http://www.gore.com

14 http://www.sglcarbon.com/index.html 
15 D. Hissel, M.-C. Péra, D. Candusso, F. Harel, S. Bégot, Characterization of Polymer Electrolyte Fuel Cell for embedded generators. Test bench design and methodology. Chapter of Advances in fuel cells, Research Signpost, Editor Xiang-Whu Zhang, North Carolina State Univ., 2005.

16 http://www.zahner.de

17 Y. Nagahara, S. Sugawara, K. Shinohara, The impact of air contaminants on PEMFC performance and durability, J. Power Sources 182 (2008), pp. 422-428.

18 A. Pozio, M. De Francesco, A. Cemmi, F. Cardellini, L. Giorgi, Comparison of high surface Pt/C catalysts by cyclic voltammetry, J. Power Sources 105 (2002) 13-19.

19 S. Ge, C.Y. Wang, Cyclic Voltammetry Study of Ice Formation in the PEFC Catalyst Layer during Cold Start, J. Electrochem. Soc. 154 (2007) B1399B1406.

20 B. Wahdame, D. Candusso, X. François, F. Harel, J.-M. Kauffmann, G. Coquery, Design of experiment techniques for fuel cell characterisation and development, Int. J. Hydrogen Energy 34 (2009) 967-980.

21 J. Larminie, A. Dicks, Fuel cell systems explained (2nd ed.), John Wiley, 2003.

22 M.A.R.S. Al-Baghdadi, H.A.K. Shahad Al-Janabia, Effect of operating parameters on the hygro-thermal stresses in proton exchange membranes of fuel cells, Int. J. Hydrogen Energy 17 (2007) 4510-4522.

23 J-H. Jang, H-C. Chiu, W-M. Yan, W-L. Sun, Effects of operating conditions on the performances of individual cell and stack of PEM fuel cell, J. Power Sources 180 (2008) 476-483.

24 W-M. Yan, C-Y. Chen, S-C. Mei, C-Y. Soong, F. Chen, Effects of operating conditions on cell performance of PEM fuel cells with conventional or interdigitated flow field, J. Power Sources 162 (2006) 1157-1164.

25 M. Amirinejad, S. Rowshanzamir, M.H. Eikani, Effects of operating parameters on performance of a proton exchange membrane fuel cell, J. Power Sources 161 (2006) 872-875.

26 J. Zhang, Y. Tang, C. Song, J. Zhang, Polybenzimidazole-membrane-based PEM fuel cell in the temperature range of $120-200^{\circ} \mathrm{C}$, J. Power Sources 172 (2007) 163-171.

27 X. Cheng, J. Zhang, Y. Tang, C. Song, J. Shen, D. Song, J. Zhang, Hydrogen crossover in high-temperature PEM fuel cells, J. Power Sources 167 (2007) 2531.

28 S. S. Kocha, J. D. Yang, J. S. Yi, Characterization of Gas Crossover and Its Implications in PEM Fuel Cells, AIChE Journal 52 (2006) 1916 - 1925.

29 V. Ramani, H. R. Kunz, J. M. Fenton, Stabilized heteropolyacid/Nafion ${ }^{\circledR}$ composite membranes for elevated temperature/low relative humidity PEFC operation, Electrochim. Acta 50 (2005) 1181-1187.

30 R. Solasi, Y. Zou, X. Huang, K. Reifsnider, D. Condit, On mechanical behavior and in-plane modeling of constrained PEM fuel cell membranes subjected to hydratation and temperature cycles, J. Power Sources 167 (2007) 366-377.

31 J. Zhang, Y. Tang, C. Song, Z. Xia, H. Li, H. Wang, J. Zhang, PEM fuel cell relative humidity $(\mathrm{RH})$ and its effect on performance at high temperatures, Electrochim. Acta 53 (2008) 5315-5321. 
32 X.-D. Wang, Y.-Y. Duan, W.-M. Yan, F.-B. Weng, Effect of humidity of reactants on the cell performance of PEM fuel cells with parallel and interdigitated flow field designs, J. Power Sources 176 (2008) 247-258.

33 F. Urbani, O. Barbera, G. Giacoppo, G. Squadrito, E. Passalacqua, Effect of operative conditions on a PEFC stack performance, Int. J. Hydrogen Energy 33 ( $2008) 3137-3141$.

34 C. Song, C. J. Chua, Y. Tang, J. L. Zhang, J. Zhang, J. Li, K. Wang, S. McDermid, P. Kozak, Voltage jump during polarization of a PEM fuel cell operated at low relative humidities, Int. J. Hydrogen Energy 33 (2008) 28022807.

35 R. Jiang, H. R. Kunz, J. M. Fenton, Investigation of membrane property and fuel cell behavior with sulfonated poly(ether ether ketone) electrolyte: Temperature and relative humidity effects, J. Power Sources 150 (2005) 120-128.

36 A. Taniguchi, T. Akita, K. Yasuda, Y. Miyazaki, Analysis of electrocatalyst degradation in PEMFC caused by cell reversal during fuel starvation, J. Power Sources 130 (2004) 42-49.

37 N. Yousfi-Steiner, Ph. Moçotéguy, D. Candusso, D. Hissel, A. Hernandez, A. Aslanides, A review on PEM voltage degradation associated with water management: Impacts, influent factors and characterization, Journal of Power Sources 183 (2008) 260-274.

38 B. Wahdame, D. Candusso, F. Harel, X. François, M.-C. Péra, D. Hissel, J.-M. Kauffmann, Analysis of a PEMFC durability test under low humidity conditions and stack behaviour modelling using experimental design techniques, J. Power Sources 182 (2008) 429-440.

39 B. Wahdame, D. Candusso, X. François, F. Harel, A. De Bernardinis, J.-M. Kauffmann, G. Coquery, Study of a 5kW PEMFC using experimental design and statistical analysis techniques. Fuel Cells from Fundamentals to Systems 7 (2007) 47-62.

40 J. Zhang, Y. Tang, C. Song, J. Zhang, H. Wang, PEM fuel cell open circuit voltage $(\mathrm{OCV})$ in the temperature range of $23{ }^{\circ} \mathrm{C}$ to $120{ }^{\circ} \mathrm{C}, J$. Power Sources 163 (2006) 532-537.

41 Z. Liu, L. Yang, Z. Mao, W. Zhuge, Y. Zhang, L. Wang, Behavior of PEMFC in starvation, J. Power Sources 157 (2006) 166-176.

42 R. Cownden, M. Nahon, M.A. Rosen, Modelling and Analysis of a Solid Polymer Fuel Cell, Int. J. Hydrogen Energy 26 (2001) 615-623.

43 K. R. Minard, V. V. Viswanathan, P. D. Majors, L-Q. Wang, P. C. Rieke, Magnetic resonance imaging (MRI) of PEM dehydration and gas manifold flooding during continuous fuel cell operation, Journal of Power Sources 161 (2006) 856-863.

44 H. Tang, S. Peikang, S. P. Jiang, F. Wang, M. Pan, A degradation study of Nafion proton exchange membrane of PEM fuel cells, Journal of Power Sources 170 (2007) 85-92. 